This is a self-archived version of an original article. This version may differ from the original in pagination and typographic details.

Author(s): Pajunen, Kalle; Järvinen, Joonas

Title: To survive or succeed? : An analysis of biotechnology firms

Year: 2018

Version: Accepted version (Final draft)

Copyright: (C) Springer Science+Business Media, LLC, part of Springer Nature 2017

Rights: In Copyright

Rights url: http://rightsstatements.org/page//nC/1.0/?language=en

Please cite the original version:

Pajunen, K., \& Järvinen, J. (2018). To survive or succeed? : An analysis of biotechnology firms.

Small Business Economics, 51(3), 757-771. https://doi.org/10.1007/s11187-017-9963-6 
To survive or succeed? An analysis of biotechnology firms

Kalle Pajunen*

Joonas Järvinen

*University of Jyväskylä

School of Business and Economics

FI-40014, University of Jyväskylä

Finland

Email: kalle.pajunen@jyu.fi

ORCID: 0000-0002-3913-7894

Conflict of Interest: The authors declare that they have no conflict of interest.

Published in:

Small Business Economics, 51(3): 757-771.

http://dx.doi.org/10.1007/s11187-017-9963-6 


\title{
To survive or succeed? An analysis of biotechnology firms
}

\begin{abstract}
In this paper, we address the question whether there exists differences in the determinants that support survival versus success of small and medium-sized high-tech firms. We examine this question in the context of Finnish biotechnology industry by analyzing the survival of all dedicated biotechnology firms in the period of 1978-2008. We argue and show that the success and survival of firms are not necessarily driven by similar determinants. Specifically, we find that while the role of different types of alliances, focused market scope as well as legitimacy of the industry seem to be important both ensuring in survival and enhancing successful performance, determinants related to sources of financing, clustering and patenting show differences in terms of how they to relate on survival and success.
\end{abstract}

Keywords: Firm survival, biotechnology; firm performance; industry environment; entrepreneurship; institutional context

JEL Classifications

L20 L25 L26 


\section{Introduction}

Firm survival is one of the most fundamental questions in research focused on entrepreneurship, organizations and strategic management resulting in a large and heterogeneous body of scholarly literature (Audretsch and Mahmood 1995; Josefy et al. 2017; Suárez and Utterback 1995). Yet, several of these studies have a unifying theme to contrasts and compare surviving and failing firms. The conceptualizations of failure and survival, however, do not capture the entire range of firm performance. Research on strategic management, in particular, has largely focused on explaining how firms are able to outperform their competitors and create competitive advantage (e.g. Durand et al. 2017); in other words, how firms are able to succeed. Thus, we can argue that failure, survival and success are distinct aspects of firm performance. This is also indicated by the different ways to operationalize and measure these concepts (Miller et al. 2013). Accordingly, besides examining the differences between failing and surviving firms, we need to acknowledge that there can potentially be differences in the determinants related to surviving versus successful firms. Earlier research has acknowledged this issue by arguing that the success and survival are potentially driven by very different conditions (e.g. Cooper 1993; Kalleberg and Leicht 1991). However, there is a need for further empirical research examining whether and why this could be the case.

In this paper, we seek to advance the literature on firm survival (e.g. Audretsch and Mahmood 1995; Geroski et al. 2010; Josefy et al. 2017; Strotmann 2007) by examining this issue in the context of small and medium-sized, dedicated biotechnology firms (DBFs). Biotechnology is an example of an industry that has experienced a notable growth during the last 40 years in terms of its economic significance, number of dedicated firms, number of specific sectors, and geographical scope of activities. At the same time, however, only a 
minority of DBFs earn profits and are considered successful (Lazonick and Tulum 2011; Pisano 2006). In fact, the primary challenge, or even goal, for a large number of DBFs is to ensure their survival. Interestingly, scholars have provided notable efforts to identify conditions that support DBFs to outperform their competitors in terms of profitability. Yet, it is largely an open question whether the survival of DBFs can also be supported via these same conditions. Indeed, if biotechnology firms seek to ensure their survival and public authorities wish to support a vivid biotechnology industry, understanding of the nature of the conditions that specifically support firm survival is crucial. We examine this issue by identifying firm and industry specific factors (cf. Audretsch et al. 2000) that earlier biotechnology-related research has found to explain successful performance of firms and, thereafter, explore the effects of these determinants on firm survival in the context of the Finnish biotechnology industry. We do this via survival analysis of a unique dataset of the Finnish DBFs from the very first entries until the end of 2008.

We contribute to the literature on firm survival by showing how and why DBF survival is driven by somewhat different determinants than the success of DBFs. In particular, we show that while the role of different types of alliances, focused market scope as well as legitimacy of the industry seem to be important both ensuring survival and enhancing successful performance of firms, determinants related to sources of financing, clustering and patenting show differences in terms of how they relate on survival and success. Altogether, our findings provide important policy relevant knowledge of what institutional, industry- and firm-level factors should be developed in order to keep the firms alive. 


\section{Theoretical background}

By building on earlier research related on successful performance and growth of DBFs, we theorize how firm specific issues related to (1) alliances, (2) financing, (3) patents, and (4) products as well as industry characteristics related to (5) cluster location, (6) biotechnology sector, and (7) industry density influence firm survival. Because our study is exploratory in nature, we do not formulate explicit hypotheses.

\subsection{Alliances}

A number of studies in general and related to biotechnology industry in particular have identified a positive relationship between number of alliances (all types of alliances) and firm performance (Deeds and Hill 1996; Durand et al. 2008; Niosi 2003; Oliver 2001; Powell et al. 1996; Quintana-Garcia and Benavides-Velasco 2004; Rothaermel and Deeds 2006; Silverman and Baum 2002). Alliances are generally considered a means by which new firms obtain the resources and capabilities that are required to successfully compete in the industry. Alliances may also aid firms in defraying costs and sharing risk (Stuart 2000) and in helping to signal the quality of the firm (Baum et al. 2000; Baum and Silverman 2004; Stuart et al. 1999). In order to capture the effects of different types of alliance relationships in the value chain (cf. Silverman and Baum 2002), we also categorize alliances into vertical downstream, vertical upstream and horizontal alliances. Altogether, based on earlier research, we can tentatively expect to find a positive relationship between number of alliances (and different alliance types) and firm survival.

\subsection{Financing}


Earlier research emphasizes the role of financing as an important determinant of the performance of biotechnology firms and, in general, identifies a positive relationship between the amount of financing that a firm has received and various measures of performance (Aharonson et al. 2008; Bagchi-Sen and Scully 2004; Hall and Bagchi-Sen 2002; Niosi 2003). However, earlier research has suggested that it is possible that different types of financing may have different effects on performance. For example, Ahmed and Cozzarin (2009) suggest that receiving financing in the form of angel, venture and conventional forms contributes more significantly to successful firm performance than does obtaining financing from government, IPO and alliance capital sources. Thus, the source of financing may have a notable influence on whether it specifically enhances DBFs success or survival. Yet, we can tentatively expect to find that receiving financing has a positive effect on firm survival.

\subsection{Patenting}

Patents are typically important for biotechnology firms. They help delay imitation by other firms, protect a firm's gains from R\&D spending and product introductions (Zahra 1996), and provide access to critical complementary assets (Pisano 1990). Patents also signal the future innovative potential of the firm (Baum and Silverman 2004). Although most studies identify a positive effect between patenting activity and firm performance (DeCarolis and Deeds 1999; Niosi 2003; Silverman and Baum 2002), also somewhat contrasting results exist. In particular, Durand et al. (2008) found a negative relationship between patents and the short-term profitability biotechnology firms. Thus, while could tentatively assume that patenting has a positive effect on survival, this relationship requires further examination.

\subsection{Products on the market}


The products that a firm has on the market are a frequently used measure of the performance of biotechnology firms (Quintana-Garcia and Benavides-Velasco 2004; Renko et al. 2009; Rothaermel and Deeds 2006). It is also acknowledged that biotechnology firms that are able to launch their products quickly are more successful than are firms with slower product development processes (Deeds and Hill 1996; Hall and Bagchi-Sen 2002). Although a new firm can survive for a period of time by relying on external financing, sufficiently rapid commercialization of its technologies can be essential for long-term survival. Thus, we expect to find a positive relationship between number of products on the market and firm survival.

\subsection{Location in cluster}

Biotechnology firms are commonly clustered around centers of scientific excellence. Many studies suggest that firms that are located in these geographical clusters are more successful (DeCarolis and Deeds 1999; Deeds et al. 1997; Folta et al. 2006), largely due to economies of agglomeration and knowledge spillovers (Audretsch 2001; Folta et al. 2006; Niosi and Bas 2001). Yet, researchers also find complications to this argument (e.g., van Geenhuizen and Reyes-Gonzalez 2007; Gilding 2008; Tsvetkova et al. 2014). In particular, the effect of cluster location is considered to be contingent on its characteristics, such as size. For example, Folta et al. (2006) found that there is an inversed U-shaped relationship between the size of a cluster and firm performance. We examine whether cluster size also has an inverted U-shaped effect on survival. Furthermore, we consider the characteristics of the cluster more extensively by operationalizing the construct of cluster vitality (cf. Porter and Stern 2002).

2.6 Biotechnology sector and related business models 
Despite some common characteristics, firms in different sectors of the biotechnology industry operate under different environmental constraints, resulting in differences in not only firms' expected level of performance but also business models (Lazonick and Tulum 2011). We suggest that the sector affects firm survival in three distinct ways. First, research that controls for sector-related performance differences using dummies often finds performance differences between sectors (Baum and Silverman 2004; Belussi et al. 2010; Folta et al. 2006; Niosi 2003; McCann and Folta 2011). Thus, we expect that the sector has a direct effect on performance. Second, because firms in different sectors face different environmental constraints and operate by different business models, the biotechnology sector can function as a moderator between different determinants of performance and performance outcomes. It seems particularly important to distinguish between firms focusing on services and those focusing on products (Casper 2000; Durand et al. 2008; Mangematin et al. 2003). Third, regarding the market scope, we could assume that there is a need to focus on one biotechnology sector or technology $y^{1}$. Considering the scarceness of resources of new biotechnology firms and the long product development times, this argument is justifiable. Thus, we expect to find a negative effect between the number of sectors in which the firm operates and firm survival.

\subsection{Industry density}

Earlier biotechnology-related research has used industry density as a control variable due to its frequently significant effect on firm performance (Baum and Silverman 2004; Folta et al. 2006; Silverman and Baum 2002; Stuart et al. 1999). However, because density has

\footnotetext{
${ }^{1}$ Some earlier research uses scope as a control variable, but the results are inconclusive and mixed
} (Baum et al. 2000; Folta et al. 2006). 
been shown to have a complex relationship with firm performance (Carroll and Hannan 2000), we further examine these more complicated density-related arguments.

First, according to the theory of density dependence (Hannan and Carroll 1992), industry density should have a U-shaped effect on firm performance. Density can be used as a proxy for two main processes that drive population evolution: legitimation and competition. In the beginning of evolution, an increasing density increases the legitimacy of the population, lowering the rate of firm failure. Further increases in density, however, bring the population toward its environmental carrying capacity in terms of scarce resources and produce competition among the firms, increasing the rate of firm failure. Thus, we expect that density should have a U-shaped relationship with rate of firm failure.

Second, we consider whether the sector-level or industry-level density is most important to individual firms. The processes of legitimation and competition may operate on different levels, with legitimation typically operating on a broader scale than competition (Carroll and Hannan 2000). We assume that competition largely occurs at the level of individual sub-sectors because the resource requirements of firms differ by sector.

Furthermore, the process of legitimation may operate more at the industry level because firms share a common identity as biotechnology firms (cf. Mattsson 2008). Altogether, the increasing density of firms may increase the social acceptance of the industry and benefit all firms. Thus, we expect that at the sector level, density has a U-shaped effect on the rate of firm failure. At the industry level, density may only have a negative effect on rate of firm failure because only the legitimation process operates at this level. 


\section{Methodology}

3.1 Data

We analyze a complete life-history dataset of the modern biotechnology industry in Finland from 1978 to 2008 . We consider that this period is sufficiently long to reveal the dominant conditions influencing firm survival. We have excluded the years following the global financial crisis, which had a notable negative impact on the different spheres of Finland's economy. Since the complex effects of this macroeconomic downturn would have been difficult to control, we consider that our analysis period is able to tell accurately about the firm and industry specific conditions related to DBFs' survival. The dataset includes information on 195 firms operating in 12 biotechnology sectors ${ }^{2}$. The unique dataset is compiled by aggregating data from several sources. These sources include existing company listings (The Index of Biotechnology Companies, Organizations and Research Institutes in Finland, which is published annually by the Finnish Bioindustries Association (FIB) between 1997-2008), news sources (Kemia-Kemi 1974-2008; Kauppalehti 1974-2008; Insinööriuutiset and Tekniikka \& Talous 1974-2008), National board of patents and registration of Finland (NBPR), historical documents, and interviews. The dataset includes firm entry and exit dates, firm characteristics and all biotechnology-related news and articles, which were coded from the abovementioned news sources. Multiple news sources also enabled us to implement data triangulation.

We complemented the dataset by retrieving longitudinal data on firm characteristics such as size, ownership status, and location from Statistics Finland. Esp@cenet was searched for all patents that the firms had filed and been granted on a global scale. Patents that were

\footnotetext{
2 The sectors are biopharmaceuticals, diagnostics, agrobiotech, bioinformatics, biomaterials, bioproduction, industrial enzymes, the environment, functional food, bioenergy, devices, and R\&D services.
} 
issued in many countries were only coded once. Finally, some of the financing-related data were gathered from the SDC Platinum database.

\subsection{Dependent variable}

We used firm survival as direct measure of our dependent variable. In essence, if a firm is not able to survive, it makes exit from the market (e.g. Agarwal and Sarkar 2002; Klepper 2002). Specifically, we defined exit as the failure of a firm or closure of a subsidiary (cf. Baum 1996). A firm failed if it went bankrupt or if its value-added tax liability expired. We also detected 17 acquisitions and mergers that led to the discontinuance of a firm. Because acquisitions and mergers such as these may not always imply failure, we treated these cases as right-censored.

\subsection{Independent variables}

To examine industry density, we used three variables. The first, $N_{\text {ind }}$, summed the number of firms at the industry level. Second, at the sector level, we used two variables $\left(N_{\text {sect }}\right.$ and $N_{\text {sect }}{ }^{2}$ ) that summed the number of firms in all sectors in which the focal firm was active. Next, we used three measures to study the effect of cluster location. The first measure was a dummy variable (cluster), which was coded as "one" for new firms that are located in a geographical cluster (Helsinki, Espoo, Vantaa, Kauniainen, Turku, Tampere, Kuopio, or

Oulu) $)^{3}$, and "zero" otherwise. The second measure is the size of the cluster (cluster size and cluster size $e^{2}$. For this measure, we counted the number of firms in the cluster in which the focal firm was located. The third measure, cluster vitality (cluster vitality), was constructed by evaluating all news articles related to the five clusters in the database and by identifying the crucial events in their evolution. We also analyzed the number of university departments and research institutes in each cluster, the number of critical service providers for biotechnology

\footnotetext{
${ }^{3}$ Helsinki, Espoo, Vantaa, and Kauniainen form the capital region cluster.
} 
firms, and the number and types of firms operating in the clusters. We ranked the clusters according to these characteristics and assigned tentative values for cluster vitality using 11value scaling (i.e., $0,0.1,0.2, \ldots, 0.9,1)$. The scores were discussed with two industry experts, and minor changes were made based on their suggestions.

To adjust for the expected direct performance differences between the sectors, we created the following five dummy variables: (1) biopharmaceuticals, (2) diagnostics and devices, (3) biomaterials, (4) industrial and green biotechnology, and (5) $R \& D$ services. We performed this aggregation because many of the sectors are small and the basic characteristics and the environmental constraints of the firms can be considered similar. We measured market scope as the number of sectors in which a focal firm was active. Products on the market was operationalized as a categorical variable that received a value of $0,0.25,0.5,0.75$ or 1 based on the number of products that the firm had on the market. A score of 0 was assigned to firms with no products and a score 0.25 to firms that did not have products on the market but were, for example, close to licensing their products. A score of 0.5 was assigned to firms that had at least one product, a score of 0.75 to firms with two to four products, and a score of 1 to firms that had more products on the market.

To measure the overall amount of financing that the firms had received (tot financing), we created a dummy variable that was coded "one" after the year the firm received either private equity financing or public financing for the first time. We searched the SDC Platinum database for equity investments made to the firms. This database did not cover all the placements and did not include the amount of financing for every placement, therefore we also searched the news event database for financing-related news events (the search resulted in more than 1,000 events). Finally, we reviewed a list of financing decisions made in the $21^{\text {st }}$ century by TEKES; the most important source of public financing in Finland. Based on this information, we assigned values for the dummy variable. Yet, we were not able to find the 
exact amount of financing in all cases; thus, we used only a dummy ${ }^{4}$. To measure the separate effects of private financing and public financing, we created two dummy variables (private fin and public fin) based on the overall financing variable and the abovementioned data sources.

Number of alliances was measured as the count of all alliances and collaborative relationships of the firm. We calculated its value by summing the number of the firm's vertical upstream, vertical downstream, and horizontal alliances. We treated the variable as cumulative. To assess the effects of different types of alliances in the value chain (cf. Silverman and Baum 2002), we created three variables (downstream, upstream and horizontal) based on the total number of alliances variable. Downstream alliances connect DBFs to sources of complementary assets (e.g. production facilities), knowledge commercialization (e.g. marketing expertise), and financing outside of the industry boundaries. Upstream alliances connect DBFs with universities and other research institutes that provide them with additional scientific and technological knowledge. Horizontal alliances connect DBFs to other firms in the same industry.

Patenting activity was operationalized as the cumulative yearly updated number of patents granted to a biotechnology firm (patents). We assigned a patent to a firm at the date of application rather than the date of granting. Prior research (e.g. Ernst 2001) has shown that this better takes into consideration the point of time the actual innovation has been made. We included information on patents that were granted up to the end of 2010.

We controlled for the effects of firm size, firm age and the status of firm ownership (cf. Cefis and Marsili 2005). Also, to capture trends in the failure rate that are a function of historical time, we introduced a year control variable (year of the observation minus 1978).

${ }^{4}$ Although the variable may not be able to differentiate between firms that receive a large amount of financing from those that only receive a small amount, we also estimated models in which the construct was operationalized as the cumulative number of financing placements made to a firm. These two operationalizations led to the same results. 
To take into account changes in the institutional environment, we used two dummy variables. The first reflected a major change when Finland joined the European Union in 1995. The second captured the post-2000 period of declining funding of the biotechnology industry and the slowdown in the worldwide economy after the 1990-2000 general overheating. Finally, we controlled for the possibility that the changes in GDP affect the rate of firm failure (GDP). Data for the GDP variable were retrieved from the Groningen total economy database (www.ggdc.net/databases/ted.htm).

\subsection{Analytic method and model specification}

Hazard rate methodology was used to estimate the models for the dependent variable. Specifically, we employed the semi-parametric Cox proportional hazards model (Cox 1972; 1975). This specifies the hazard of firm exit as

$$
\mathrm{h}(\mathrm{t}, \mathbf{x}(\mathrm{t}), \beta)=\mathrm{h}_{0}(\mathrm{t}) \mathrm{e}^{\left[\mathbf{x}^{\prime}(\mathrm{t}) \beta\right]}
$$

where $h_{0}(t)$ is the unknown baseline hazard function; $\boldsymbol{x}(\boldsymbol{t})$ denotes the vector of covariates expected to shift the hazard of exit proportionally in each year; and $\beta$ is a vector of parameters to be estimated (Hosmer and Lemeshow 1999, 250). The advantage of using the Cox proportional hazards model is that one does not need to make parametric assumptions about the form of duration dependence in the hazard rate (Cleves et al. 2004). This analytic method has been used by Audretsch and Mahmood (1995) to analyze new firm survival and, for example, by Boyer and Blazy (2014) in their analysis of survival of micro-startups. In addition, the findings of Cader and Leatherman (2011) provide strong support for the use of Cox hazard models for firm survival analysis.

To run the models, we divided the life histories of each firm into one-year periods to incorporate time-varying covariates, yielding 1703 periods. If not otherwise mentioned, the values of the variables were updated yearly. The analysis period started from the beginning of 
1978, and the end date of the analysis was the end of 2008. All variables were lagged one year to avoid problems of simultaneity. The models were estimated by the method of maximum likelihood using STATA 9.0. Table 1 presents the descriptive statistics. No high correlations were found among the independent variables expect for the correlations between the measures of cluster location, between the measures of total sources of finance and private and public financing, and between the total number of alliances and different types of alliances. Due to possible multicollinearity, we entered total and sub-effects into separate models. 
Table 1 Descriptive statistics and correlations for the variables

\begin{tabular}{|c|c|c|c|c|c|c|c|c|c|c|c|c|c|c|c|c|c|c|c|}
\hline Variable & Mean & S.D. & 1 & 2 & 3 & 4 & 5 & 6 & 7 & 8 & 9 & 10 & 11 & 12 & 13 & 14 & 15 & 16 & 17 \\
\hline 1. Cluster & 0.837 & 0.370 & 1.0000 & & & & & & & & & & & & & & & & \\
\hline 2.Cluster size & 19.403 & 15.086 & 0.5671 & 1.0000 & & & & & & & & & & & & & & & \\
\hline 3. Cluster size 2 & 603.919 & 626.067 & 0.4266 & 0.9728 & 1.0000 & & & & & & & & & & & & & & \\
\hline 4. Cluster vitality & 0.603 & 0.328 & 0.8012 & 0.8722 & 0.7581 & 1.0000 & & & & & & & & & & & & & \\
\hline 5. Capital region & 0.326 & 0.469 & 0.3086 & 0.3830 & 0.3320 & 0.3358 & 1.0000 & & & & & & & & & & & & \\
\hline 6. Market scope & 1.523 & 0.813 & 0.0968 & 0.0265 & 0.0098 & 0.0559 & 0.1290 & 1.0000 & & & & & & & & & & & \\
\hline 7. Total financing & 0.489 & 0.500 & 0.0413 & 0.1731 & 0.1961 & 0.0977 & 0.0089 & -0.0063 & 1.0000 & & & & & & & & & & \\
\hline 8. Private fin. & 0.263 & 0.440 & 0.0436 & 0.0647 & 0.0690 & 0.0735 & -0.0082 & 0.0751 & 0.5942 & 1.0000 & & & & & & & & & \\
\hline 9. Public fin. & 0.446 & 0.497 & 0.0897 & 0.2384 & 0.2540 & 0.1643 & 0.0415 & -0.1109 & 0.9077 & 0.4418 & 1.0000 & & & & & & & & \\
\hline 10. Products in market & 0.340 & 0.424 & -0.2092 & -0.1267 & -0.0836 & -0.2071 & -0.0361 & -0.1024 & 0.2447 & 0.1806 & 0.2493 & 1.0000 & & & & & & & \\
\hline 11. Number of alliances & 2.245 & 3.442 & 0.1003 & 0.1591 & 0.1458 & 0.1570 & 0.1496 & -0.0373 & 0.4107 & 0.3652 & 0.4327 & 0.4155 & 1.0000 & & & & & & \\
\hline 12. Upstream & 1.138 & 2.026 & 0.0665 & 0.1080 & 0.0882 & 0.1171 & 0.1703 & -0.0320 & 0.3290 & 0.2398 & 0.3467 & 0.3382 & 0.8219 & 1.0000 & & & & & \\
\hline 13. Downstream & 0.856 & 1.669 & 0.0815 & 0.1459 & 0.1430 & 0.1230 & 0.1029 & -0.0325 & 0.3549 & 0.3529 & 0.3801 & 0.3869 & 0.8063 & 0.3876 & 1.0000 & & & & \\
\hline 14. Horizontal & 0.248 & 0.781 & 0.0916 & 0.1083 & 0.1083 & 0.1227 & -0.0043 & -0.0179 & 0.2068 & 0.2387 & 0.2036 & 0.1324 & 0.5478 & 0.2026 & 0.4161 & 1.0000 & & & \\
\hline 15. Patents & 3.487 & 8.446 & 0.1320 & 0.1343 & 0.1256 & 0.1395 & 0.0542 & -0.0554 & 0.3373 & 0.3351 & 0.3667 & 0.3045 & 0.6205 & 0.3780 & 0.6684 & 0.3297 & 1.0000 & & \\
\hline 16. Biopharmaceuticals & 0.240 & 0.427 & 0.0989 & 0.0900 & 0.0832 & 0.1302 & -0.0906 & 0.2386 & 0.0647 & 0.1233 & 0.0775 & -0.2871 & 0.0088 & 0.0065 & -0.0052 & 0.0376 & 0.0126 & 1.0000 & \\
\hline 17. Diagnostics and devices & 0.367 & 0.482 & 0.1280 & 0.0695 & 0.0399 & 0.0997 & 0.1510 & 0.2843 & 0.0080 & 0.0217 & 0.0073 & 0.3282 & 0.1533 & 0.1416 & 0.1261 & 0.0422 & 0.0626 & -0.1393 & 1.0000 \\
\hline 18. Biomaterials & 0.141 & 0.348 & 0.0889 & -0.0254 & -0.0402 & 0.0271 & -0.1901 & -0.1351 & 0.0376 & 0.0371 & 0.0458 & -0.0524 & -0.0768 & -0.0571 & -0.0473 & -0.0859 & 0.1479 & -0.1371 & -0.2425 \\
\hline 19. Ind. and green biotech & 0.301 & 0.459 & -0.2772 & -0.1829 & -0.1409 & -0.2646 & 0.1073 & 0.2579 & -0.1101 & -0.0432 & -0.1622 & 0.0420 & -0.0995 & -0.0255 & -0.1092 & -0.1449 & -0.1895 & -0.1766 & -0.3056 \\
\hline 20. R\&D-service & 0.246 & 0.431 & 0.0873 & 0.1702 & 0.1713 & 0.1536 & 0.0232 & 0.2801 & -0.0682 & -0.1246 & -0.0795 & -0.3378 & -0.1656 & -0.1816 & -0.1558 & 0.0630 & -0.1841 & 0.0441 & -0.1428 \\
\hline 21. Size (In) & 1.438 & 1.576 & 0.0757 & 0.0599 & 0.0600 & 0.0501 & 0.0942 & -0.0505 & 0.5228 & 0.4212 & 0.5270 & 0.5002 & 0.6660 & 0.4754 & 0.6191 & 0.3848 & 0.5553 & -0.0105 & 0.1824 \\
\hline 22. Age & 5.906 & 5.484 & 0.0061 & 0.1406 & 0.1629 & 0.0682 & 0.0360 & -0.0529 & 0.2721 & 0.2138 & 0.2853 & 0.4128 & 0.5379 & 0.3754 & 0.4920 & 0.3527 & 0.5291 & -0.1528 & 0.1621 \\
\hline 23. Ownership status & 0.148 & 0.355 & -0.1430 & -0.0818 & -0.0568 & -0.1334 & -0.0074 & 0.0217 & 0.0838 & 0.0341 & 0.0569 & 0.2355 & 0.1806 & 0.0910 & 0.2272 & 0.0780 & 0.1676 & -0.0780 & 0.0453 \\
\hline 24. $N_{\text {ind }}$ & 92.763 & 36.591 & -0.0023 & 0.4916 & 0.5362 & 0.3079 & -0.0889 & -0.1375 & 0.2442 & 0.0534 & 0.3087 & -0.0140 & 0.0791 & 0.0304 & 0.0696 & 0.1237 & 0.1270 & 0.1157 & -0.1320 \\
\hline 25. $N_{\text {sect }}$ & 26.168 & 11.091 & -0.0130 & 0.4519 & 0.4885 & 0.2731 & 0.0101 & -0.0510 & 0.1834 & 0.0045 & 0.2357 & 0.0622 & 0.1277 & 0.0714 & 0.1013 & 0.1619 & 0.0442 & 0.0129 & 0.1751 \\
\hline 26. $\mathrm{N}_{\text {sect }}{ }^{4}$ & 80.769 & 54.725 & 0.0191 & 0.4356 & 0.4801 & 0.2461 & 0.0207 & -0.0426 & 0.1923 & -0.0010 & 0.2418 & 0.0621 & 0.1186 & 0.0546 & 0.0981 & 0.1724 & 0.0367 & -0.0147 & 0.1998 \\
\hline 27. Year & 26.210 & 6.201 & -0.0088 & 0.4792 & 0.5191 & 0.2979 & -0.1044 & -0.1423 & 0.2371 & 0.0354 & 0.3028 & -0.0133 & 0.0851 & 0.0380 & 0.0749 & 0.1190 & 0.1360 & 0.1155 & -0.1351 \\
\hline 28. P1, 1995- & 0.791 & 0.407 & 0.0059 & 0.4246 & 0.4333 & 0.3320 & -0.0809 & -0.1194 & 0.1290 & 0.0224 & 0.1840 & -0.0453 & 0.0583 & 0.0304 & 0.0392 & 0.0935 & 0.0793 & 0.1098 & -0.1031 \\
\hline 29. $P 2,2001-$ & 0.503 & 0.500 & 0.0263 & 0.4071 & 0.4809 & 0.1506 & -0.0402 & -0.0938 & 0.3166 & 0.0766 & 0.3742 & 0.0236 & 0.0606 & 0.0005 & 0.0704 & 0.1178 & 0.1316 & 0.0764 & -0.0955 \\
\hline 30. GDP & 0.999 & 0.169 & 0.0244 & 0.4780 & 0.5317 & 0.2672 & $\begin{array}{l}-0.0689 \\
\end{array}$ & -0.1303 & 0.2819 & 0.0526 & 0.3454 & 0.0038 & 0.0782 & 0.0227 & 0.0753 & 0.1298 & 0.1469 & 0.0976 & -0.1245 \\
\hline
\end{tabular}


Table 1 (continues)

\begin{tabular}{|c|c|c|c|c|c|c|c|c|c|c|c|c|c|}
\hline Variable & 18 & 19 & 20 & 21 & 22 & 23 & 24 & 25 & 26 & 27 & 28 & 29 & 30 \\
\hline 18. Biomaterials & 1.0000 & & & & & & & & & & & & \\
\hline 19. Ind. and green biotech & -0.2090 & 1.0000 & & & & & & & & & & & \\
\hline 20. R\&D-service & -0.2330 & -0.1299 & 1.0000 & & & & & & & & & & \\
\hline 21. Size (In) & -0.1099 & -0.1389 & -0.1688 & 1.0000 & & & & & & & & & \\
\hline 22. Age & 0.0202 & -0.1017 & -0.1096 & 0.4545 & 1.0000 & & & & & & & & \\
\hline 23. Ownership status & -0.0506 & 0.1197 & -0.1500 & 0.3252 & 0.1417 & 1.0000 & & & & & & & \\
\hline 24. $\mathrm{N}_{\text {ind }}$ & 0.0694 & -0.1447 & 0.2154 & -0.0068 & 0.2693 & -0.1150 & 1.0000 & & & & & & \\
\hline 25. $\mathrm{N}_{\text {sect }}$ & -0.3710 & -0.1141 & 0.2935 & 0.0607 & 0.2641 & -0.0794 & 0.8059 & 1.0000 & & & & & \\
\hline 26. $\mathrm{N}_{\text {sect }}^{2}$ & -0.3791 & -0.1506 & 0.3236 & 0.0806 & 0.2609 & -0.0771 & 0.7477 & 0.9741 & 1.0000 & & & & \\
\hline 27. Year & 0.0692 & -0.1433 & 0.2157 & -0.0175 & 0.2806 & -0.1137 & 0.9765 & 0.7902 & 0.7286 & 1.0000 & & & \\
\hline 28. $P 1,1995-$ & 0.0733 & -0.1356 & 0.1748 & -0.0347 & 0.2021 & -0.1230 & 0.8447 & 0.6819 & 0.5996 & 0.8063 & 1.0000 & & \\
\hline 29. P2, 2001- & 0.0314 & -0.1179 & 0.1917 & 0.0579 & 0.2472 & -0.0555 & 0.8196 & 0.6645 & 0.6764 & 0.7869 & 0.5171 & 1.0000 & \\
\hline 30. GDP & 0.0508 & -0.1368 & 0.2124 & 0.0220 & 0.2909 & -0.0866 & 0.9419 & 0.7564 & 0.7284 & 0.9553 & 0.7231 & 0.8414 & 1.0000 \\
\hline
\end{tabular}

\section{Results}

The results of the analyses are presented in Table 2 (variables are defined in section 3.1.). Model 1 includes all of the control variables. In models $2-4$, we add the three different variables one by one to test the effect of cluster location on the hazard of failure. None of the variables (cluster dummy, cluster size and cluster size ${ }^{2}$, and cluster vitality) reach statistical significance. The same applies to full models (see models 15 and 16). Here, we report only those full models (i.e., 15 and 16) that include the cluster vitality variable (as the effect is closest to statistical significance of the used cluster location variables). However, we also test full models in which the other two cluster location variables are present and note that their effects are nonsignificant and that the coefficients for the other variables of interest remain the same as in models 15 and $16^{5}$.

\footnotetext{
${ }^{5}$ These models are available by request.
} 
Table 2 Estimated Cox hazard-rate models for the failure of the Finnish biotechnology firms

\begin{tabular}{|c|c|c|c|c|c|c|c|c|c|c|c|c|c|c|c|c|c|c|}
\hline Variables & Model 1 & Model 2 & Model 3 & Model 4 & Model 5 & Model 6 & Model 7 & Model 8 & Model 9 & Model 10 & Modd 11 & Model 12 & Model 13 & Model 14 & Modd 15 & Model 16 & Moddl 17 & Model 18 \\
\hline \multicolumn{19}{|l|}{ Firm-specific variables } \\
\hline Cluster & & $\begin{array}{l}-0.114 \\
(0.345)\end{array}$ & & & & & & & & & & & & & & & & \\
\hline Cluster size & & & $\begin{array}{c}0.032 \\
(0.044)\end{array}$ & & & & & & & & & & & & & & & \\
\hline Cluster size ${ }^{<}$ & & & $\begin{array}{l}-0.001 \\
(0.001)\end{array}$ & & & & & & & & & & & & & & & \\
\hline Cluster vitality & & & & $\begin{array}{c}0.077 \\
(0.442)\end{array}$ & & & & & & & & & & & $\begin{array}{l}-0.567 \\
(0.585)\end{array}$ & $\begin{array}{l}-0.603 \\
(0.585)\end{array}$ & $\begin{array}{l}-2.363 \\
(2.348)\end{array}$ & $\begin{array}{l}-0.382 \\
(0.631)\end{array}$ \\
\hline Capital region & & & & & $\begin{array}{l}0.751^{*} \\
(0.286)\end{array}$ & & & & & & & & & & $\begin{array}{l}0.997 * \\
(0.395)\end{array}$ & $\begin{array}{l}1.006^{*} \\
(0.394)\end{array}$ & $\begin{array}{c}4.081 \\
(4.770)\end{array}$ & $\begin{array}{l}0.379^{*} \\
(0.235)\end{array}$ \\
\hline Market scope & & & & & & $\begin{array}{l}0.576 * * \\
(0.120)\end{array}$ & & & & & & & & & $\begin{array}{c}0.633^{* *} \\
(0.242)\end{array}$ & $\begin{array}{l}0.623^{*} \\
(0.244)\end{array}$ & & $\begin{array}{l}0.646^{*} \\
(0.266)\end{array}$ \\
\hline Total financing & & & & & & & $\begin{array}{l}-0.000 \\
(0.326)\end{array}$ & & & & & & & & & & & \\
\hline Private fin. & & & & & & & & $\begin{array}{l}1.044 * * \\
(0.346)\end{array}$ & & & & & & & $\begin{array}{l}1.263^{* *} \\
(0.423)\end{array}$ & $\begin{array}{c}1.297 * * \\
(0.427)\end{array}$ & $\begin{array}{l}3.906^{*} \\
(1.764)\end{array}$ & $\begin{array}{l}0.828 \dagger \\
(0.504)\end{array}$ \\
\hline Public fin. & & & & & & & & $\begin{array}{l}-0.896^{*} \\
(0.340)\end{array}$ & & & & & & & $\begin{array}{c}-0.703^{*} \\
(0.420)\end{array}$ & $\begin{array}{c}-0.717^{*} \\
(0.420)\end{array}$ & $\begin{array}{l}-2.087 \\
(1.767)\end{array}$ & $\begin{array}{l}-0.857 \dagger \\
(0.492)\end{array}$ \\
\hline Products in market & & & & & & & & & $\begin{array}{c}-0.694 \dagger \\
(0.434)\end{array}$ & & & & & & $\begin{array}{l}-0.722 \\
(0.541)\end{array}$ & $\begin{array}{l}-0.706 \\
(0.544)\end{array}$ & $\begin{array}{l}-1.007 \\
(4.371)\end{array}$ & $\begin{array}{l}-1.243^{*} \\
(0.599)\end{array}$ \\
\hline Number of alliances & & & & & & & & & & $\begin{array}{c}-0.247^{*} \\
(0.103)\end{array}$ & & & & & $\begin{array}{c}-0.346 * * \\
(0.127)\end{array}$ & & $\begin{array}{l}-0.792 \dagger \\
(0.442)\end{array}$ & $\begin{array}{c}-0.325^{*} \\
(0.158)\end{array}$ \\
\hline Upstream & & & & & & & & & & & $\begin{array}{l}-0.138 \\
(0.135)\end{array}$ & & & & & $\begin{array}{l}-0.283 \dagger \\
(0.168)\end{array}$ & & \\
\hline Downstream & & & & & & & & & & & $\begin{array}{l}-0.386^{*} \\
(0.214)\end{array}$ & & & & & $\begin{array}{l}-0.460^{*} \\
(0.239)\end{array}$ & & \\
\hline Horizontal & & & & & & & & & & & $\begin{array}{l}-0.420 \\
(0.431)\end{array}$ & & & & & $\begin{array}{l}-0.252 \\
(0.513)\end{array}$ & & \\
\hline Patents & & & & & & & & & & & & $\begin{array}{l}-0.055 \\
(0.052)\end{array}$ & & & $\begin{array}{l}-0.001 \\
(0.049)\end{array}$ & $\begin{array}{c}0.002 \\
(0.050)\end{array}$ & $\begin{array}{c}0.159 \\
(0.460)\end{array}$ & $\begin{array}{c}0.012 \\
(0.054)\end{array}$ \\
\hline Biopharmaceuticals & & & & & & & & & & & & & $\begin{array}{l}0.882^{* *} \\
(0.334)\end{array}$ & & $\begin{array}{c}0.157 \\
(0.470)\end{array}$ & $\begin{array}{c}0.146 \\
(0.472)\end{array}$ & & $\begin{array}{c}0.276 \\
(0.544)\end{array}$ \\
\hline Diagnostics and devices & & & & & & & & & & & & & $\begin{array}{l}0.605 \dagger \\
(0.310)\end{array}$ & & $\begin{array}{l}-0.125 \\
(0.515)\end{array}$ & $\begin{array}{l}-0.142 \\
(0.516)\end{array}$ & & $\begin{array}{c}0.353 \\
(0.561)\end{array}$ \\
\hline Biomaterials & & & & & & & & & & & & & $\begin{array}{l}-0.102 \\
(0.523)\end{array}$ & & $\begin{array}{c}0.137 \\
(0.761)\end{array}$ & $\begin{array}{c}0.167 \\
(0.769)\end{array}$ & & $\begin{array}{c}0.175 \\
(0.823)\end{array}$ \\
\hline Ind. and green biotech & & & & & & & & & & & & & $\begin{array}{l}1.370^{* *} \\
(0.344)\end{array}$ & & $\begin{array}{c}0.483 \\
(0.569)\end{array}$ & $\begin{array}{c}0.481 \\
(0.569)\end{array}$ & & $\begin{array}{l}1.103^{*} \\
(0.536)\end{array}$ \\
\hline$R \& D$-service & & & & & & & & & & & & & $\begin{array}{l}-0.042 \\
(0.360)\end{array}$ & & $\begin{array}{c}-1.030^{*} \\
(0.484)\end{array}$ & $\begin{array}{l}-1.008^{*} \\
(0.489)\end{array}$ & & \\
\hline
\end{tabular}


Table 2 (continues) Estimated Cox hazard-rate models for the failure of the Finnish biotechnology firms

\begin{tabular}{|c|c|c|c|c|c|c|c|c|c|c|c|c|c|c|c|c|c|c|}
\hline Variables & Model 1 & Model 2 & Model 3 & Model 4 & Model 5 & Model 6 & Model 7 & Model 8 & Modle 9 & Model 10 & Modd 11 & Model 12 & Model 13 & Model 14 & Model 15 & Model 16 & Model 17 & Model 18 \\
\hline Size (In) & $\begin{array}{c}-0.485 * * \\
(0.127)\end{array}$ & $\begin{array}{c}-0.480 * * \\
(0.127)\end{array}$ & $\begin{array}{c}-0.498 * * \\
(0.128)\end{array}$ & $\begin{array}{c}-0.487 * * \\
(0.128)\end{array}$ & $\begin{array}{c}-0.512^{* *} \\
(0.128)\end{array}$ & $\begin{array}{c}-3.385^{* *} \\
(0.127)\end{array}$ & $\begin{array}{c}-0.450^{* *} \\
(0.138)\end{array}$ & $\begin{array}{c}-0.445^{* *} \\
(0.145)\end{array}$ & $\begin{array}{c}-0.468^{* *} \\
(0.136)\end{array}$ & $\begin{array}{l}-0.276 \dagger \\
(0.147)\end{array}$ & $\begin{array}{l}-0.272 \dagger \\
(0.150)\end{array}$ & $\begin{array}{c}-0.461 * * \\
(0.141)\end{array}$ & $\begin{array}{c}-0.421 * * \\
(0.128)\end{array}$ & $\begin{array}{c}-0.432 * * \\
(0.122)\end{array}$ & $\begin{array}{l}-0.225 \\
(0.186)\end{array}$ & $\begin{array}{c}-0.237 \\
(0.190)\end{array}$ & $\begin{array}{l}-0.644 \\
(0.819)\end{array}$ & $\begin{array}{l}-0.098 \\
(0.212)\end{array}$ \\
\hline Age & $\begin{array}{l}-1.225^{*} \\
(0.560)\end{array}$ & $\begin{array}{l}-1.248^{*} \\
(0.564)\end{array}$ & $\begin{array}{l}-1.241^{*} \\
(0.563)\end{array}$ & $\begin{array}{l}-1.222 * \\
(0.560)\end{array}$ & $\begin{array}{l}-1.379^{*} \\
(0.565)\end{array}$ & $\begin{array}{l}-0.499 \\
(0.578)\end{array}$ & $\begin{array}{l}-1.197^{*} \\
(0.565)\end{array}$ & $\begin{array}{l}-0.701 \\
(0.579)\end{array}$ & $\begin{array}{l}-1.065 \dagger \\
(0.568)\end{array}$ & $\begin{array}{l}-1.106^{*} \\
(0.559)\end{array}$ & $\begin{array}{l}-1.108^{*} \\
(0.560)\end{array}$ & $\begin{array}{l}-1.156 * \\
(0.564)\end{array}$ & $\begin{array}{l}-0.685 \\
(0.579)\end{array}$ & $\begin{array}{c}-1.556^{* *} \\
(0.549)\end{array}$ & $\begin{array}{l}-0.101 \\
(0.223)\end{array}$ & $\begin{array}{c}-0.111 \\
(0.235)\end{array}$ & $\begin{array}{c}-2.130 \\
N A\end{array}$ & $\begin{array}{c}0.469 \\
(0.653)\end{array}$ \\
\hline Ownership status & $\begin{array}{l}0.707 \dagger \\
(0.386)\end{array}$ & $\begin{array}{l}0.675 \dagger \\
(0.398)\end{array}$ & $\begin{array}{l}0.764 \dagger \\
(0.392)\end{array}$ & $\begin{array}{l}0.718 \dagger \\
(0.442)\end{array}$ & $\begin{array}{l}0.710 \dagger \\
(0.384)\end{array}$ & $\begin{array}{c}0.669 \\
(0.409)\end{array}$ & $\begin{array}{l}0.695 \dagger \\
(0.386)\end{array}$ & $\begin{array}{c}0.603 \\
(0.386)\end{array}$ & $\begin{array}{l}0.857^{*} \\
(0.396)\end{array}$ & $\begin{array}{l}0.718 \dagger \\
(0.397)\end{array}$ & $\begin{array}{l}0.712 \dagger \\
(0.399)\end{array}$ & $\begin{array}{l}0.717 \dagger \\
(0.388)\end{array}$ & $\begin{array}{l}0.476 \\
(0.400)\end{array}$ & $\begin{array}{c}0.634 \\
(0.386)\end{array}$ & $\begin{array}{c}0.612 \\
(0.436)\end{array}$ & $\begin{array}{c}0.624 \\
(0.438)\end{array}$ & $\begin{array}{l}-2.106 \\
(3.804)\end{array}$ & $\begin{array}{c}0.701 \\
(0.496)\end{array}$ \\
\hline \multicolumn{19}{|c|}{ Environmental variables } \\
\hline \multirow[t]{2}{*}{$\overline{N_{\text {ind }}}$} & & & & & & & & & & & & & & -0.022 & -0.044 & -0.044 & 0.086 & -0.054 \\
\hline & & & & & & & & & & & & & & $(0.030)$ & $(0.034)$ & $(0.034)$ & $(0.233)$ & $(0.038)$ \\
\hline \multirow[t]{2}{*}{$\mathrm{N}_{\text {sect }}$} & & & & & & & & & & & & & & $-0.190^{*}$ & $-0.262^{*}$ & $-0.273^{*}$ & -3.150 & $-0.280 \dagger$ \\
\hline & & & & & & & & & & & & & & $(0.100)$ & $(0.123)$ & $(0.125)$ & (2.951) & $(0.145)$ \\
\hline \multirow[t]{2}{*}{$\mathrm{N}_{\text {sect }}{ }^{2}$} & & & & & & & & & & & & & & $0.031^{*}$ & $0.03 y^{*}$ & $0.041^{*}$ & 0.464 & $0.045 \dagger$ \\
\hline & & & & & & & & & & & & & & $(0.018)$ & $(0.021)$ & $(0.022)$ & $(0.416)$ & $(0.026)$ \\
\hline Year & $\begin{array}{c}0.067 \\
(0.103)\end{array}$ & $\begin{array}{c}0.063 \\
(0.103)\end{array}$ & $\begin{array}{c}0.065 \\
(0.103)\end{array}$ & $\begin{array}{c}0.066 \\
(0.103)\end{array}$ & $\begin{array}{c}0.107 \\
(0.103)\end{array}$ & $\begin{array}{c}0.168 \\
(0.111)\end{array}$ & $\begin{array}{c}0.074 \\
(0.103)\end{array}$ & $\begin{array}{c}0.104 \\
(0.106)\end{array}$ & $\begin{array}{c}0.080 \\
(0.104)\end{array}$ & $\begin{array}{c}0.092 \\
(0.103)\end{array}$ & $\begin{array}{c}0.090 \\
(0.103)\end{array}$ & $\begin{array}{c}0.055 \\
(0.104)\end{array}$ & $\begin{array}{c}0.118 \\
(0.104)\end{array}$ & $\begin{array}{c}0.037 \\
(0.162)\end{array}$ & $\begin{array}{c}0.269 \\
(0.180)\end{array}$ & $\begin{array}{c}0.266 \\
(0.180)\end{array}$ & $\begin{array}{c}0.243 \\
(1.364)\end{array}$ & $\begin{array}{c}0.212 \\
(0.206)\end{array}$ \\
\hline P1 & $\begin{array}{l}-0.637 \\
(0.637)\end{array}$ & $\begin{array}{l}-0.630 \\
(0.638)\end{array}$ & $\begin{array}{l}-0.708 \\
(0.645)\end{array}$ & $\begin{array}{c}-0.649 \\
(0.641)\end{array}$ & $\begin{array}{c}-0.722 \\
(0.641)\end{array}$ & $\begin{array}{l}-0.702 \\
(0.649)\end{array}$ & $\begin{array}{c}-0.697 \\
(0.640)\end{array}$ & $\begin{array}{l}-0.751 \\
(0.645)\end{array}$ & $\begin{array}{l}-0.687 \\
(0.644)\end{array}$ & $\begin{array}{l}-0.666 \\
(0.638)\end{array}$ & $\begin{array}{l}-0.681 \\
(0.639)\end{array}$ & $\begin{array}{c}-0.841 \\
(0.671)\end{array}$ & $\begin{array}{l}-0.673 \\
(0.644)\end{array}$ & $\begin{array}{l}-0.549 \\
(0.868)\end{array}$ & $\begin{array}{l}-0.691 \\
(0.895)\end{array}$ & $\begin{array}{l}-0.698 \\
(0.893)\end{array}$ & $\begin{array}{c}-44.114 \\
\text { NA }\end{array}$ & $\begin{array}{l}-0.215 \\
(1.023)\end{array}$ \\
\hline P2 & $\begin{array}{l}1.080 \dagger \\
(0.577)\end{array}$ & $\begin{array}{l}1.087 \dagger \\
(0.577)\end{array}$ & $\begin{array}{l}1.110 \dagger \\
0.587)\end{array}$ & $\begin{array}{l}1.083 \dagger \\
0.5771\end{array}$ & $\begin{array}{l}0.997 \dagger \\
(0.575)\end{array}$ & $\begin{array}{l}0.876 \\
(0.594)\end{array}$ & $\begin{array}{l}1.005 t \\
(0.585)\end{array}$ & $\begin{array}{l}1.012 \dagger \\
(0.579)\end{array}$ & $\begin{array}{l}0.995 t \\
(0.582)\end{array}$ & $\begin{array}{l}0.976 \dagger \\
(0.584)\end{array}$ & $\begin{array}{l}0.991 \dagger \\
(0.585)\end{array}$ & $\begin{array}{c}0.864 \\
(0601)\end{array}$ & $\begin{array}{l}1.070 \dagger \\
(0.579)\end{array}$ & $\begin{array}{l}1.551 \dagger \\
(0.822)\end{array}$ & $\begin{array}{l}1.376 \\
(0.836)\end{array}$ & $\begin{array}{l}1.371 \\
(0.835)\end{array}$ & 23.395 & $\begin{array}{l}1.127 \\
(0.901)\end{array}$ \\
\hline GDP & $\begin{array}{l}-3.090 \\
(3.400)\end{array}$ & $\begin{array}{l}-2.986 \\
(3.412)\end{array}$ & $\begin{array}{l}-3.112 \\
(3.411)\end{array}$ & $\begin{array}{l}-3.102 \\
(0.362)\end{array}$ & $\begin{array}{l}-4.067 \\
(3.423)\end{array}$ & $\begin{array}{l}-5.214 \\
-53.556)\end{array}$ & $\begin{array}{l}-2.979 \\
-(0.386)\end{array}$ & $\begin{array}{l}(0.5 / 9) \\
-2.776 \\
(3.435)\end{array}$ & $\begin{array}{l}(0.582) \\
-3.203 \\
(3.425)\end{array}$ & $\begin{array}{l}(0.584) \\
-3.577 \\
(3.444)\end{array}$ & $\begin{array}{l}(0.585) \\
-3.386 \\
(3.448)\end{array}$ & $\begin{array}{l}(0.601) \\
-1.285 \\
(3.736)\end{array}$ & $\begin{array}{l}(0.5 / 9) \\
-4.194 \\
(3.455)\end{array}$ & $\begin{array}{l}(0.822) \\
-0.698 \\
(3.651)\end{array}$ & $\begin{array}{l}(0.836) \\
-1.849 \\
(4.202)\end{array}$ & $\begin{array}{l}(0.835) \\
-1.603 \\
(4.235)\end{array}$ & $\begin{array}{c}(21.836) \\
-1.661 \\
(34.441)\end{array}$ & $\begin{array}{c}(0.901) \\
3.929 \\
(4.795)\end{array}$ \\
\hline Loglikelihood & -238.100 & -238.046 & -237.724 & -238.084 & -234.767 & -228.006 & -237.076 & -231.472 & -232.674 & -233.334 & -232.780 & -222.941 & -227.333 & -237.337 & -202.205 & -202.015 & -12.755 & -150.758 \\
\hline Chi-s & $27.00 * *$ & $27.11^{* *}$ & $27.75^{* *}$ & $27.04 * *$ & $33.67 * *$ & $47.19 * *$ & $24.15 * *$ & $35.36 * *$ & $30.82^{* *}$ & $31.64 * *$ & $32.71^{* *}$ & $30.36 * *$ & $48.54 * *$ & $28.53 * *$ & $89.96 * *$ & $87.31^{* *}$ & $45.28^{* *}$ & $66.36^{* *}$ \\
\hline Number of failures & 55 & 55 & 55 & 55 & 55 & 55 & 55 & 55 & 55 & 55 & 55 & 55 & 55 & 55 & 55 & 55 & 11 & 42 \\
\hline Number of subjects & 195 & 195 & 195 & 195 & 195 & 195 & 195 & 195 & 195 & 195 & 195 & 195 & 195 & 195 & 195 & 195 & 47 & 148 \\
\hline Number of spells & 1703 & 1703 & 1703 & 1703 & 1703 & 1703 & 1703 & 1703 & 1703 & 1703 & 1703 & 1703 & 1703 & 1703 & 1703 & 1703 & 350 & 1349 \\
\hline
\end{tabular}

${ }^{*}=p<0.01 ; *=p<0.05 ; \dagger=p<0.10$ (two-tailed tests). Standard errors in parentheses. 
To further explore our findings we add a dummy variable for firms that are located in the largest cluster of the country, namely, the capital region. The capital region is also the region with the highest level of economic activity. Interestingly, as model 5 and full models 15 and 16 show, a location in the capital region increases the hazard of failure of biotechnology firms (Model 15: 0.997, $\mathrm{p}<0.05$ ). The effect of the dummy also remains robust when entered simultaneously with the other cluster location variables. Similarly, including the dummy in the models does not affect the coefficients for the other cluster location variables.

We next test the effect of market scope on the firm hazard of failure (model 6 and full models 15 and 16) and find that a wider market scope increases the failure hazard (model 15: 0.633, $\mathrm{p}<0.01)$. To study the effect of receiving financing, we first enter a dummy variable, which includes all of the different types of financing, into model 7 and note that the variable has no effect on the failure hazard. The variable also has no effect in the full models (15 and 16). The situation changes when financing from public and private sources are treated separately. As model 8 and full models 15 and 16 suggest, the private financing dummy has a positive effect on the rate of failure (model 15: 1.263, $\mathrm{p}<0.01$ ), whereas receiving public financing seems to lower the rate of failure (model 15: $-0.703, \mathrm{p}<0.05$ ).

Model 9 adds the variable related to firms' products. Note that when the effect of the variable is estimated only with control variables included, the variable has a significant and negative effect on the firm failure hazard $(-0.694, \mathrm{p}<0.1)$. However, in full models 15 and 16, the effect of the variable is no longer significant.

Concerning the number of alliances, model 10 first includes the variable of total number of alliances. Matching our expectation, the variable has a negative effect on the failure hazard of the firms $(-0.247, \mathrm{p}<0.05)$. The effect also remains in the full model (model 15: $-0.346, \mathrm{p}<0.01)$. To further explore whether the effect of alliances varies by alliance type, we enter separate variables for upstream, downstream, and horizontal alliances into model 11. 
According to the model, only the hazard-lowering effect of downstream alliances is statistically significant $(-0.386, \mathrm{p}<0.05)$. The effects of upstream and horizontal alliances are also negative but not statistically significant. When full model 16 is considered, the hazardlowering effect of downstream alliances retains its significance $(-0.460, \mathrm{p}<0.05)$. In addition, the negative effect of upstream alliances becomes statistically significant $(-0.283, \mathrm{p}<0.1)$.

As suggested by model 12 and full models 15 and 16, the number of patents seems to have no significant effect on the failure hazard. Next, concerning the direct effect of sectors, model 13 includes the biotechnology sector dummies. When their effects are estimated only with control variables included, it appears that firms in the biopharmaceutical sector $(0.882$, $\mathrm{p}<0.01)$, the diagnostics and devices sector $(0.605, \mathrm{p}<0.1)$, and the industrial and green biotech sector $(1.370, \mathrm{p}<0.01)$ face a higher hazard of failure than do firms that do not operate in these sectors. However, when full models 15 and 16 are considered, the effects of the sector variables change. Specifically, firms in the service sector have a significantly lower hazard of failure (model 15: $-1.030, \mathrm{p}<0.05$ ) than do firms that do not operate in the sector.

When examining the effect of industry density, we note that sector-level density has a U-shaped effect on failure hazard. In contrast to our expectations, industry-level density has a nonsignificant hazard-lowering effect on the rate of failure. Thus, the industry-level legitimation does not play a role in the current research context ${ }^{6}$.

Next, to explore whether firms' business model moderates the effects of other determinants of interest, we divide the sample into two sub-samples and run models that are separate from those with all of the variables included. The first sub-sample consists of service-focused biotechnology firms (see model $11^{7}$ ), and the second consists of product-

\footnotetext{
${ }^{6}$ We also test models in which a squared industry-level density variable is included. This does not change the results.

${ }^{7}$ Because the sub-sample of service-oriented firms includes only 350 observations, the results should be interpreted with caution. The market scope variable and sector dummies are not included in model 17 because
} 
focused firms (see model 12). Cluster vitality (nonsignificant), private financing (3.906, $\mathrm{p}<0.05$ for service firms, $0.828, \mathrm{p}<0.1$ for product firms $)$, number of alliances $(-0.792, \mathrm{p}<0.1$ for service firms, $-0.325, \mathrm{p}<0.05$ for product firms), and number of patents (nonsignificant) have similar effects for firms in the two sub-samples and the sub-samples and the whole sample. The first difference is related to the effect of the capital region dummy; the hazardincreasing effect of the variable is significant only for service-focused firms $(4.081, \mathrm{p}<0.05$ for service firms). Second, the failure-decreasing effect of public financing is statistically significant only for product-focused firms $(-0.857, \mathrm{p}<0.1)$. Third, products on the market has a negative and statistically significant effect only on the failure of product-focused firms (1.243, $\mathrm{p}<0.05)$. Finally, density has a statistically significant $U$-shaped effect on failure hazard only for product-focused firms $\left(\mathrm{N}_{\text {sect }}-0.280, \mathrm{p}<0.1, \mathrm{~N}_{\text {sect }}^{2} 0.045, \mathrm{p}<0.1\right)$.

\section{Discussion and conclusion}

We examined the question of firm survival and success in the context of the Finnish biotechnology industry. We provided a contribution to the literature on firm survival (Audretsch and Mahmood 1995; Cooper 1993; Geroski et al. 2010; Josefy et al. 2017; Kalleberg and Leicht 1991; Strotmann 2007) by arguing and showing that survival and success are distinct dimensions of performance and that they are not necessarily driven by similar determinants. Our findings also offer policy relevant implications that help to explain and understand how the firm and industry related factors facilitate or constrain the survival of small and medium-sized high-technology firms. Next, we discuss about these theoretical and practical implications of our study.

service firms predominantly operate in one sector. Due to the small number of observations in the service sector sub-sample, we do not add lower-level alliance variables into the models. 
First, our findings indicate that extensive networks both in terms of upstream and downstream alliances enhance the survival possibilities of DBFs. Thus, an access to external resources and capabilities is not only important in terms of enhancing successful performance (e.g. Rothaermel and Deeds 2006), but it is an important aspect in ensuring the survival as well. Similarly, we show that it is important for the industry to achieve "critical mass" and legitimacy to enable firm survival. Although a greater number of firms is typically associated with a higher level of competition, our results indicate that the competitive effect starts to dominate only after a certain density has been reached. Before that point, increasing density increases firms' life chances.

Our findings regarding financing, clustering and patenting show that the survival of DBFs is also dependent on conditions that are not typically linked with the successful performance of small and medium-sized high-technology firms. First, we find that the total equity financing that the DBFs have received has no statistically significant effect on firm failure. However, when we divide the financing into public and private sources, the results suggest that private financing has a positive effect on firm failure rate, whereas public financing has a significant negative effect on firm failure rate. In other words, public financing can be considered as having an important positive effect on firm survival.

As a clear policy implication, this finding indicates that the source of finance matters, and as regards to the question of firm survival it is likely to be different compared to the source of financing of the most successful DBFs (cf. Ahmed and Cozzarin 2009). Indeed, in the context of Finland, the public sources for financing (i.e. TEKES and SITRA) have had central roles in the financing of biotechnology firms (Hermans et al. 2006). Although TEKES and SITRA both strive for financing R\&D activities that have a commercial potential, it can be argued that in comparison to private financing, this type of public financing is more inefficient or hesitant in distinguishing potentially successful firms from unsuccessful firms. 
Regarding the effects of clusters, we find that neither location in a biotechnology cluster nor cluster characteristics have a statistically significant effect on firm failure. This result is not in line with most of the earlier studies focused on explaining successful performance of firms (DeCarolis and Deeds 1999; Folta et al. 2006; McCann and Folta 2011; Stuart and Sorenson 2003). While we conclude that DBFs can survive without being located in clusters, we also consider potential context-related explanations for our finding. The first explanation relates to the size of Finland and relatively short distances between firms compared to those in North America. The entire Finnish biotechnology industry may be considered as one coherent cluster. Second, many entrepreneurs have networked with one another during their years of education related to biotechnology and may already have functioning relationships with parties that can help them run their own business.

Interestingly, however, we find that those firms that are located in the largest agglomeration of biotechnology firms and Finnish economic activity in general, the capital region of Helsinki, face a significantly higher risk of failure than do firms that are located outside of the region. This higher risk exists despite the many important external resources for biotechnology firms that are present in the capital region. We consider that one reason for this finding is that a strong biotechnology identity has not developed in the capital region because biotechnology-related activities are scattered around the region. Furthermore, the industry has not achieved any special role in the capital region because the economic significance of the industry has been relatively small. By contrast, in smaller cities a stronger identity has developed around biotechnology. In these cities biotechnology-related activities are highly concentrated in certain geographical areas and the municipalities have played an active role in supporting the development of the clusters (Höyssä et al. 2004). Altogether, research on industrial identities and cluster construction (Romanelli and Khessina 2005) supports our suggestion regarding the role of the cluster's identity on the firm survival. 
We also find that the number of patents does not have a significant effect on firm failure hazard. This finding clarifies the somewhat mixed results of earlier research (see Deeds et al. 1997; Durand et al. 2008). That is, a successful firm may benefit from a versatile and valuable patent portfolio, but our findings suggest that patenting may not be a critical condition in order to ensure the survival. Earlier research has mostly agreed that patents are important for the successful performance of biotechnology firms (e.g. DeCarolis and Deeds 1999; Niosi 2003; Silverman and Baum 2002). However, Durand et al. (2008) found a negative relationship between patents and the short-term profitability of French biotechnology firms. Furthermore, the findings of Hyytinen et al. (2015) as well as Boyer and Blazy (2014) show that innovative start-ups and micro-enterprises are more likely to fail than their noninnovative counterparts. Our findings add on this body of knowledge by showing that while successful DBFs may benefit from a versatile and valuable patent portfolio, patenting may not be a critical determinant to ensure that the firm is able to survive. One core issue related to this is the notable expenditures that a patenting firm has to be committed before any economic value becomes certain. Basically, a DBF that is trying to survive may not be willing or capable to make such investments.

Our results also show that firm business model, in terms of service- or productorientation, may have both direct and indirect effects on the rate of firm failure. In general, firms in the service sector seem to have a lower failure hazard than do firms in other sectors. This finding is understandable because service firms are often able to achieve revenues and profits shortly after their founding. The results also propose that business model may moderate the relationships between other determinants and firm survival. For example, we find that products on the market have a statistically significant hazard-lowering effect only for product-oriented firms. Finally, our findings suggest that in terms of survival it is beneficial if the firm is focused on a single or few sectors. 
As shown, these findings provide clear managerial implications for new entrepreneurs, firms that are facing the challenge of survival, and political decision-makers trying to create a favorable environment for the industry. In particular, the role of public financing should not be underestimated. We may consider it as a mechanism to the industry to achieve "critical mass" that we found also supporting firm survival. Creation of stronger cluster identities, in turn, is an issue that is closely linked to the nurturing of long-term cooperation between regional authorities and the specific industry. Yet, much research remains to be done to fully understand the role that the heterogeneity of the industry plays in the survival and success of the firms in different industrial and institutional contexts (cf. Audretsch et al. 2000). Furthermore, we do not argue that our study has captured all factors that may have positive effects on firm survival. Indeed, considering the causal complexity related to the topic, future researcher could also apply configurational methods to consider how the determinants interact with one another and how firms may choose different paths to ensure the desired outcome. 


\section{References}

Agarwal, R., \& Sarkar, M. B. (2002). The conditioning effect of time on firm survival: An industry life cycle approach. Academy of Management Journal, 45(5), 971-994. https://doi.org/10.2307/3069325

Aharonson, B. S., Baum, J. A. C. \& Plunket, A. (2008). Inventive and uninventive clusters: The case of Canadian biotechnology. Research Policy, 37, 1108-1131. https://doi.org/10.1016/j.respol.2008.04.008

Ahmed, S. \& Cozzarin, B. P. (2009). Start-up funding sources and biotechnology firm growth. Applied Economics Letters, 16(13), 1341-1345. http://dx.doi.org/10.1080/13504850701367338

Audretsch, D. (2001). The role of small firms in U.S. biotechnology clusters. Small Business Economics, 17, 3-15. https://doi.org/10.1023/A:1011140014334

Audretsch, D. B. \& Mahmood, T. (1995). New firm survival: new results using a hazard function. Review of Economics and Statistics, 77(1), 97-103.

Audretsch, D. B., Houweling, P., \& Thurik, A. R. (2000). Firm survival in the Netherlands. Review of Industrial Organization, 16(1), 1-11. https://doi.org/10.1023/A:1007824501527

Bagchi-Sen, S. \& Scully, J. L. (2004). The Canadian environment for innovation and business development in the biotechnology industry: a firm-level analysis. European Planning Studies, 12(7), 961-983. http://dx.doi.org/10.1080/0965431042000267867

Baum, J. A. C. (1996). Organizational Ecology. Handbook of Organizations Studies. C. C. Hardy and N. W.R. Thousands Oaks, CA, Sage: 77-114.

Baum, J. A. C., Calabrese, T. \& Silverman, B. S. (2000). Don't go it alone: Alliance network composition and startups' performance in Canadian biotechnology. Strategic Management Journal, 21(3), 267-294. http://dx.doi.org/10.1002/(SICI)10970266(200003)21:3<267::AID-SMJ89>3.0.CO;2-8

Baum, J. A. C. \& Silverman, B. S. (2004). Picking winners or building them? Alliance, intellectual, and human capital as selection criteria in venture financing and performance of biotechnology startups. Journal of Business Venturing, 19(3), 411436. https://doi.org/10.1016/S0883-9026(03)00038-7

Belussi, F., Sammarra, A. \& Sedita, S. R. (2010). Learning at the boundaries in an Open Regional Innovation System: A focus on firms' innovation strategies in the Emilia Romagna life science industry. Research Policy, 39(6), 710-721. https://doi.org/10.1016/j.respol.2010.01.014

Boyer, T. \& Blazy, R. (2014). Born to be alive? The survival of innovative and noninnovative French micro-start-ups. Small Business Economics, 42(4), 669-683. https://doi.org/10.1007/s11187-013-9522-8

Cader, H. A. \& Leatherman, J. C. (2011). Small business survival and sample selection bias. Small Business Economics, 37(2), 155-165. https://doi.org/10.1007/s11187-009-92404

Carroll, G. R. \& Hannan, M. T. (2000). The Demography of Corporations and Industries. Princeton, N.J., Princeton University Press.

Casper, S. (2000). Institutional adaptiveness, technology policy, and the diffusion of new business models: the case of German biotechnology. Organization Studies, 21(5), 887914. https://doi.org/10.1177/0170840600215003

Cefis, E., \& Marsili, O. (2005). A matter of life and death: innovation and firm survival. Industrial and Corporate Change, 14(6), 1167-1192. https://doi.org/10.1093/icc/dth081 
Cleves, M., Gould, W. \& Gutierrez, R. (2004). An introduction to survival analysis using Stata. Texas, Stata press.

Cooper, A. C. (1993). Challenges in predicting new firm performance. Journal of Business Venturing, 8(3), 241-253. https://doi.org/10.1016/0883-9026(93)90030-9

Cox, D. R. (1972). Regression models and life tables. Journal of the Royal Statistical Society, B, 26, 186-220.

Cox, D. R. (1975). Partial likelihood. Biometrika, 62(2), 269-276.

DeCarolis, D. M. \& Deeds, D. L. (1999). The impact of stocks and flows of organizational knowledge on firm performance: An empirical investigation of the biotechnology industry. Strategic Management Journal, 20(10), 953-968. https://doi.org/10.1002/(SICI)1097-0266(199910)20:10<953::AID-SMJ59>3.0.CO;23

Deeds, D. L., Decarolis, D. \& Coombs, J. E. (1997). The impact of firm-specific capabilities on the amount of capital raised in an initial public offering: Evidence from the biotechnology industry. Journal of Business Venturing, 12(1), 31-46. https://doi.org/10.1016/S0883-9026(97)84970-1

Deeds, D. L. \& Hill, C. W. L. (1996). Strategic alliances and the rate of new product development: An empirical study of entrepreneurial biotechnology firms. Journal of Business Venturing, 11(1), 41-55. https://doi.org/10.1016/0883-9026(95)00087-9

Durand, R., Bruyaka, O. \& Mangematin, V. (2008). Do science and money go together? The case of the French biotech industry. Strategic Management Journal, 29, 1281-1299. https://doi.org/10.1002/smj.707

Durand, R., Grant, R. M., \& Madsen, T. L. (2017). The expanding domain of strategic management research and the quest for integration. Strategic Management Journal, 38(1), 4-16. https://doi.org/10.1002/smj.2607

Ernst, H. (2001). Patent applications and subsequent changes of performance: evidence from time-series cross-section analyses on the firm level. Research Policy, 30, 143-157. https://doi.org/10.1016/S0048-7333(99)00098-0

Folta, T. B., Cooper, A. C. \& Baik, Y. (2006). Geographic cluster size and firm performance. Journal of Business Venturing, 21(2), 217-242. https://doi.org/10.1016/j.jbusvent.2005.04.005

Geroski, P. A., Mata, J., \& Portugal, P. (2010). Founding conditions and the survival of new firms. Strategic Management Journal, 31(5), 510-529. https://doi.org/10.1002/smj.823

Gilding, M. (2008). 'The tyranny of distance': Biotechnology networks and clusters in the antipodes. Research Policy, 37, 1132-1144. https://doi.org/10.1016/j.respol.2008.04.004

Hall, L. A. \& Bagchi-Sen, S. (2002). A study of R\&D, innovation, and business performance in the Canadian biotechnology industry. Technovation, 22(4), 231-244. https://doi.org/10.1016/S0166-4972(01)00016-5

Hannan, M. T. \& Carroll, G. R. (1992). Dynamics of organizational populations: density, legitimation, and competition. New York, Oxford University Press.

Hermans, R. and Kulvik, M. (2006). Sustainable biotechnology development - New insights into Finland. Helsinki, Taloustieto.

Hosmer, D. W. \& Lemeshow, S. (1999). Applied survival analysis: regression modelling of time to event data. Chichester, John Wiley.

Hyytinen, A., Pajarinen, M., \& Rouvinen, P. (2015). Does innovativeness reduce startup survival rates? Journal of Business Venturing, 30(4), 564-581. https://doi.org/10.1016/j.jbusvent.2014.10.001 
Höyssä, M., Bruun, H. \& Hukkinen, J. (2004). The co-evolution of social and physical infrastructure for biotechnology innovation in Turku, Finland. Research Policy, 33, 769-785. https://doi.org/10.1016/j.respol.2003.12.003

Josefy, M. A., Harrison, J. S., Sirmon, D. G., \& Carnes, C. (2017). Living and dying: Synthesizing the literature on firm survival and failure across stages of development. Academy of Management Annals, 11(2), 770-799. https://doi.org/10.5465/annals.2015.0148

Kalleberg, A. L. \& Leicht, K. T. (1991). Gender and organizational performance: Determinants of small business survival and success. Academy of Management Journal, 34(1), 136-161. https://doi.org/10.2307/256305

Klepper, S. (2002). Firm survival and evolution of oligopoly. The RAND Journal of Economics, 33(1), 37-61.

Lazonick, W., \& Tulum, Ö. (2011). US biopharmaceutical finance and the sustainability of the biotech business model. Research Policy, 40, 1170-1187. https://doi.org/10.1016/j.respol.2011.05.021

Mangematin, V., Lemarie, S., Boissin, J. P., Catherine, D., Corolleur, F., Coronini, R. \& Trommetter, M. (2003). Development of SMEs and heterogeneity of trajectories: The case of biotechnology in France. Research Policy, 32(4), 621-638. https://doi.org/10.1016/S0048-7333(02)00045-8

Mattsson, J. T. (2008). Organizational diversity and industry evolution: The entry of modern biotechnology firms in Finland 1973-2006. Espoo, Helsinki University of Technology.

McCann, B. T. \& Folta, T. B. (2011). Performance differentials within geographic clusters. Journal of Business Venturing, 26, 104-123. https://doi.org/10.1016/j.jbusvent.2009.04.004

Miller, C. C., Washburn, N. T., \& Glick, W. H. (2013). Perspective-The myth of firm performance. Organization Science, 24(3), 948-964.

Niosi, J. (2003). Alliances are not enough explaining rapid growth in biotechnology firms. Research Policy, 32(5), 737-750. https://doi.org/10.1016/S0048-7333(02)00083-5

Niosi, J. \& Bas, T. G. (2001). The competencies of regions - Canada's clusters in biotechnology. Small Business Economics, 17(1-2), 31-42. https://doi.org/10.1023/A:1011114220694

Oliver, A. L. (2001). Strategic alliances and the learning life-cycle of biotechnology firms. Organization Studies, 22(3), 467-489. https://doi.org/10.1177/0170840601223004

Pisano, G. P. (1990). The Research-and-Development Boundaries of the Firm - an EmpiricalAnalysis. Administrative Science Quarterly, 35(1), 153-176.

Pisano, G. P. (2006). Can science be a business? Lessons from biotech. Harvard Business Review, 84(10), 114-125.

Porter, M. E. \& Stern, S. (2002). The impact of location of global innovation: Findings from the national innovative capacity index. In P. K. Cornelius (ed.), The Global Competitiveness Report, pp. 227-253. New York: Oxford University Press.

pp. 227-253.Powell, W. W., Koput, K. W. \& Smith-Doerr, L. (1996). Interorganizational collaboration and the locus of innovation: Networks of learning in biotechnology. Administrative Science Quarterly, 41(1), 116-145.

Quintana-Garcia, C. \& Benavides-Velasco, C. A. (2004). Cooperation, competition, and innovative capability: a panel data of European dedicated biotechnology firms. Technovation, 24(12), 927-938. https://doi.org/10.1016/S0166-4972(03)00060-9

Renko, M., Carsrud, A. and Brannback, M. (2009). The effect of a market orientation, entrepreneurial orientation, and technological capability on innovativeness: A study of young biotechnology ventures in the United States and in Scandinavia. Journal of 
Small Business Management, 47(3), 331-369. https://doi.org/10.1111/j.1540627X.2009.00274.x

Romanelli, E., \& Khessina, O. (2005). Regional industrial identity: cluster configurations and economic development. Organization Science, 16, 344-358. https://doi.org/10.1287/orsc.1050.0131

Rothaermel, F. T. \& Deeds, D. L. (2006). Alliance type, alliance experience and alliance management capability in high-technology ventures. Journal of Business Venturing, 21(4), 429-460. https://doi.org/10.1016/j.jbusvent.2005.02.006

Silverman, B. S. \& Baum, J. A. C. (2002). Alliance-based competitive dynamics. Academy of Management Journal, 45(4), 791-806. https://doi.org/10.2307/3069312

Strotmann H. (2007). Entrepreneurial survival. Small Business Economics, 28(1), 87-104. https://doi.org/10.1007/s11187-005-8859-Z

Stuart, T. \& Sorenson, O. (2003). The geography of opportunity: spatial heterogeneity in founding rates and the performance of biotechnology firms. Research Policy, 32(2), 229-253. https://doi.org/10.1016/S0048-7333(02)00098-7

Stuart, T. E. (2000). Interorganizational alliances and the performance of firms: a study of growth and innovation rates in a high-technology industry. Strategic Management Journal, 21(8), 791-811. https://doi.org/10.1002/1097-0266(200008)21:8<791::AIDSMJ121>3.0.CO;2-K

Stuart, T. E., Hoang, H. \& Hybels, R. C. (1999). Interorganizational endorsements and the performance of entrepreneurial ventures. Administrative Science Quarterly, 44(2), 315-349. https://doi.org/10.2307/2666998

Suarez, F. F., \& Utterback, J. M. (1995). Dominant designs and the survival of firms. Strategic Management Journal, 16(6), 415-430. https://doi.org/10.2307/2666998

Tsvetkova, A., Thill, J. C., \& Strumsky, D. (2014). Metropolitan innovation, firm size, and business survival in a high-tech industry. Small Business Economics, 43(3), 661-676. https://doi.org/10.1007/s11187-014-9550-z

van Geenhuizen, M. \& Reyes-Gonzalez, L. (2007). Does a clustered location matter for hightechnology companies' performance? The case of biotechnology in the Netherlands. Technological Forecasting \& Social Change, 74, 1681-1696. https://doi.org/10.1016/j.techfore.2006.10.009

Zahra, S. A. (1996). Technology strategy and new venture performance: A study of corporatesponsored and independent biotechnology ventures. Journal of Business Venturing, 11(4), 289-321. https://doi.org/10.1016/0883-9026(95)00128-X 